\title{
模擬廃棄物層の透水特性と流出応答特性の実験的研究 Experimental Study on Permeability and Runoff Response of Model Solid Waste Layer
}

坂本康 ${ }^{*}$. 箕輪信行 ${ }^{* *}$

By Yasushi Sakamoto and Nobuyuki Minowa

\begin{abstract}
Permeability and runoff response of the unsaturated model solid waste layer were examined experimentally. The model solid waste was composed of glass beads and flexible films. Results showed that (1) films reduced the permeability, $K$ and $p\left(=\ln \left(K / K_{s}\right) / \ln \left(\theta / \theta_{s}\right)\right)$ and increased response time and frequency of small discharge, (2) the hysteresis was observed in relation between permeability and water content, and (3) mixing of glass-beads and films with water made frequency distribution of permeabilty to be more Gaussian one than mixing without water.

Keywords:model solid waste, unsaturated media, permeability, runoff response
\end{abstract}

1.はじめに

廃棄物埋立処分場内の水分移動を知ることは、処分場を適正に管理するために重要なことである。しかし 現状では、実際の処分場で水移動を観測することは不可能である。そこで、どのような性状の廃棄物のとき にどのような流れになるかを実験的に検討することが必要になっている。いわば地下水水理学に相当するよ うな、廃棄物層水理学の確立が求められている。本研究ではそのような視点で、廃棄物を抽象化した模擬廃 棄物の層について、透水性の特性および流出応答の特性を実験により検討した。本研究で模擬廃棄物と呼ん でいるものは、ガラスビーズとビニールフィルムの混合物である。この混合物を用いたのは、「複雑な廃棄 物でも、水理学的視点では、粒子状のものとそれより大きな面を持つものとの混合物として抽象化できる」 のではないかという発想に基づく。

なお、廃棄物層の水移動に関する研究は李ら (1993)、田中・松藤 (1993)などいくつかあるが、本研究のよ うに、不飽和透水倸数をそのばらつきも含めて検討した例、応答の特性を検討した例は他にない。

\section{2. 実験方法}

* 正会員 工博 山梨大学助教授 工学部土木環境工学科

( $\bar{T} 400$ 甲府市武田 4-3-11)

** 学生員 工学 山梨大学大学院修士課程 工学研究科土木環境工学専攻

( 7400 甲府市武田 4-3-11) 


\section{1 奏験装置}

装置の概要を図-1に示す。主要部分は、内径 $29.2 \mathrm{~cm}$ のアクリルパ イプを加エして作った槽と降雨装置である。槽の大きさは、実験材 料（後述）に比べ十分大きいことが必要であるが、大きすぎると水 分量を精度よく測定できない。そこで材料の少なくとも数倍程度の 大きさを採用した。槽の底には網戸に使われているナイロンメッシ

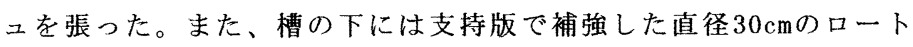
をつなげた。降雨装置は161本の注射針を $2 \mathrm{~cm}$ 間隔で網目状につけた ものである。降雨装置は定量ポンプを介して給水槽とつながってい る。給水槽はデジタル重量計の上にのっており、給水量が測定でき るようになっている。

\section{2 実験材料}

模擬廃棄物としてガラスビーズ（粒径 $0.037 \sim 13 \mathrm{~mm}, \mathrm{D}_{10}=0.078 ）$ と $10 \mathrm{~cm}$ 四方のビニールフィルムとの混合物を用いた。ガラスビーズ は12種の径の混合物である。12種の径の重量の比率は、東京三多摩 地区で実際に埋立てている焼却灰と同じになるように設定した。ま たフィルムは、厚さ0.02mmのポリエチレンを用い、大きさは同じく 東京三多摩地区の不燃物の大きさに近い $10 \mathrm{~cm}$ を採用した。

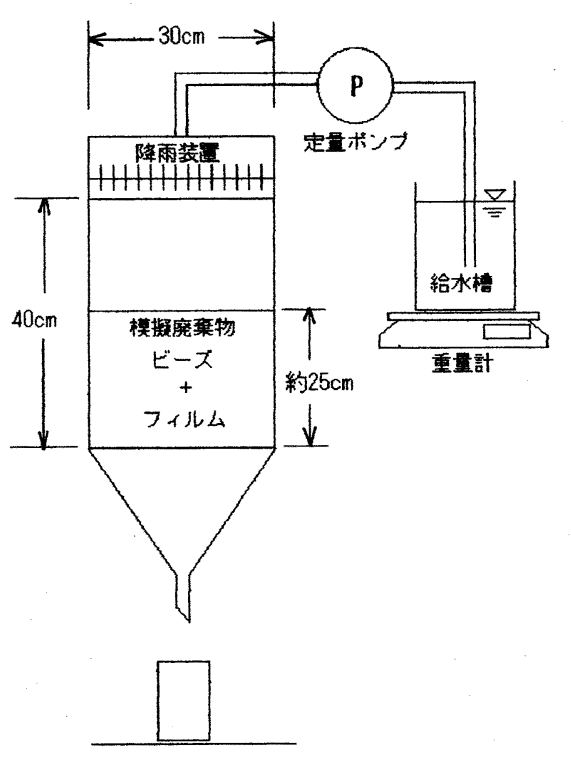

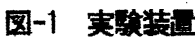

ビーズとフィルムを混合すると、フィルムはクシャ クシャに丸まったもの、折り畺まったもの、広がった ものなど様々な状態をとった。この状態を定量的に表 現することはできないが、後述の測定值のばらつきの 原因となっていると考えられる。

\section{3 実験手順}

\begin{tabular}{|c|c|c|c|c|}
\hline $\begin{array}{l}\text { 实験 } \\
\text { No. } \\
\end{array}$ & $\begin{array}{c}\text { ビーズ重量 } \\
\text { (g) }\end{array}$ & $\begin{array}{c}\text { 7仙重量 } \\
\text { (g) }\end{array}$ & $\begin{array}{c}\text { 71仙混合率 } \\
\text { (重量\%) }\end{array}$ & $\begin{array}{c}\text { 降雨強度 } \\
(\mathrm{mm} / \mathrm{h})\end{array}$ \\
\hline 1 & 33000 & 0 & 0 & 約 $25 \rightarrow 40$ \\
\hline 2. $2^{\prime}$ & 20000 & 255 & 1.26 & $\rightarrow 55 \rightarrow$ \\
\hline 3 & 10000 & 510 & 4.85 & $40 \rightarrow 25$ \\
\hline
\end{tabular}

(1)ガラスビーズとビニールフィルムを表-1の割合で混合する。混合するときに、実験 1 では水を加えず、実験 3では水を加えて混合した。水を加えた理由は、水を加えないとフィルムとガラスビーズの混合が均一に起 こらないためである。また、実験 2 と’は同じ材料で、実験 2 では水を加えずに混合し、2’では水を加えて 混合した。

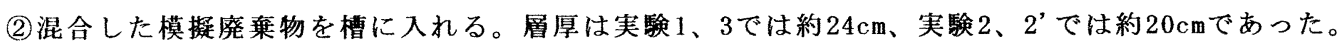

(3)槽の底を塞ぎ層中を蒸留水で飽和させた後、重力で排水する。

(4)半日程度おいて水分状態を安定させた後、降雨装置より表面に蒸留水を滴下する。このとき、5分毎の流入 量、流出量をデジタル重量計により $1 \mathrm{~g}$ 単位で測定する。

(5一定降雨強度で流入量と流出量がほぼ等しくなったら、降雨強度を表一1のように段階的に变化させる。こ の変化で約 $25 \rightarrow 40 \rightarrow 55 \mathrm{~mm} / \mathrm{h}$ と強度を増していく過程を以降降雨増加過程と呼び、逆の変化を降雨減少過程 と呼ぶ。

(6)実験終了後、水を含んだ模擬廃棄物の重量を計り貯水量を求める。この值と各時刻で測定した流入量、流 出量とから、水収支法により各時刻での体積含水率を計算する。

(7)槽内の模擬廃棄物をとりだす。同じ混合率の模擬廃棄物で再び(1)から6の作業を綝り返す。この作業を一 つの混合率についてそれぞれ5回行う。

なお、この実験条件では、(3)で飽和させた水がかなり層中に残るため、体積含水率は飽和（約 $30 \% ） に$ 狭い範囲となっている $(15 \%$ 2 $5 \%$ ）。 


\section{3. 不飽和透水倸数の特性}

\section{1 降雨増加過程と減少過程}

実験中の流出量変化の例を、実験 2 について図-2に示す。この図 で、流出量が急に増加している所が増加過程で $25 \mathrm{~mm} / \mathrm{h} か ら ~ 40 \mathrm{~mm} / \mathrm{h}$ 、 $40 \mathrm{~mm} / \mathrm{h}$ から $55 \mathrm{~mm} / \mathrm{h} に$ 降雨強度を増した所である。同じく急に減少し ている所は減少過程で $55 \mathrm{~mm} / \mathrm{h}$ から $40 \mathrm{~mm} / \mathrm{h} 、 40 \mathrm{~mm} / \mathrm{h}$ から $25 \mathrm{~mm} / \mathrm{h}$ に降雨 強度を減らした所である。

図-3から6に各実験の流出強度と体積含水率の関係を両詨数紙上に 示す。ここで流出強度とは、5分間の流出量を単位面積当り、単位時 間当りの量（フラックス）に直したものである。図中の点は、各降

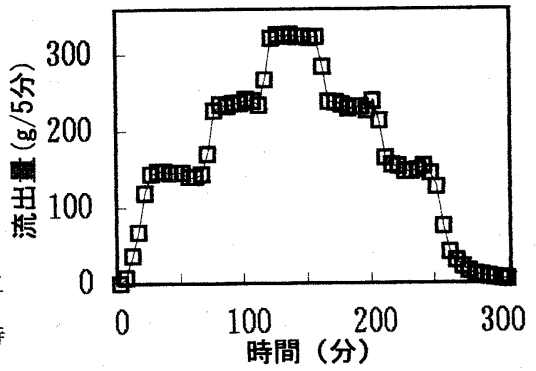

図-2＼cjkstart実験2' の流出量変化の例

雨強度で定常状態 となった時のプロ ットである。值は 定常状態での平均 值、つまり図-2で ほぼ水平な線にな っている区間での 平均値である。図 には実験 $1 、 2 、 2 ’$ 3 について5回の結 果が全て示してあ る。また降雨増加 過程と減少過程の 結果をそれぞれ別 の線で結んである。 これらの図を見る と、降雨強度が増 加するとともに流 出強度、体積含水

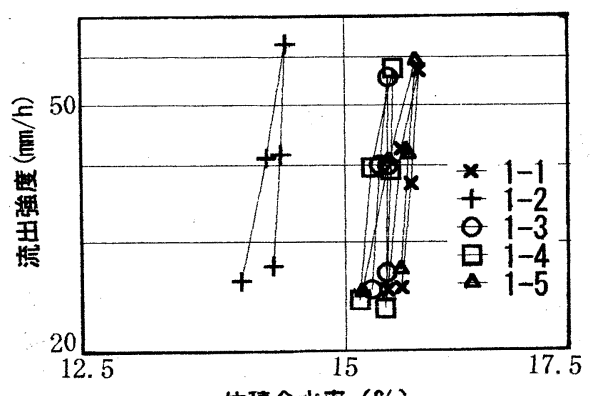

体積含水率 $(\%)$

図-3 実騦 1 の流出強度と体積含水率

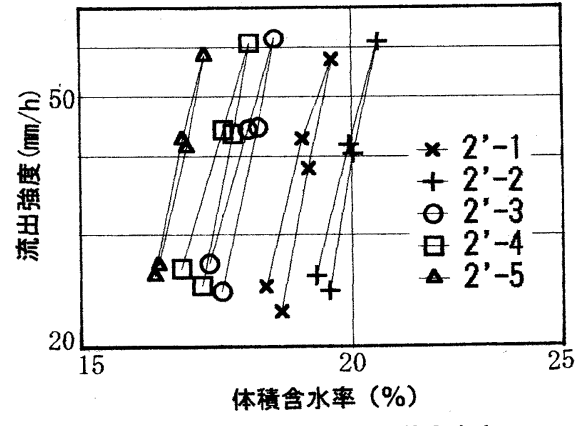

図-5 実駼2' の流出強度と体積含水率
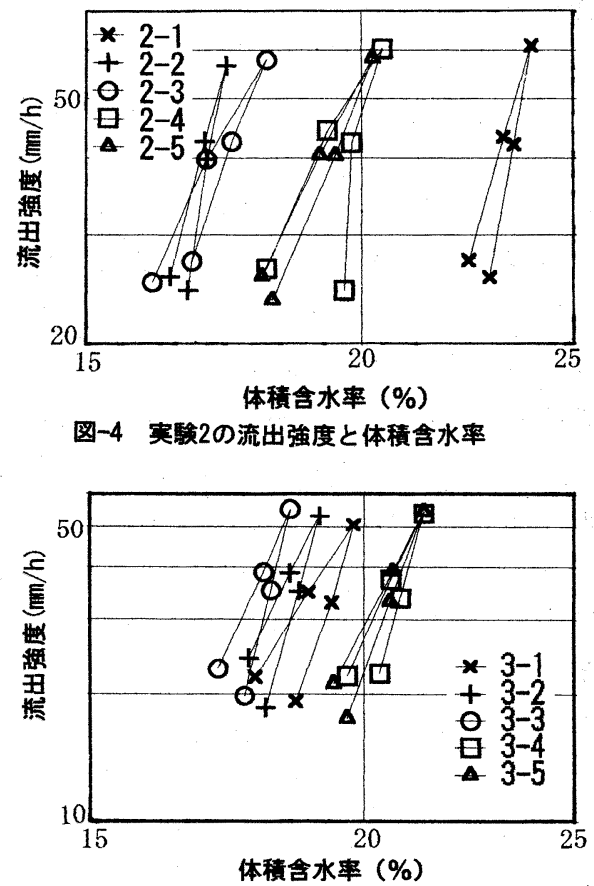

図-6 实験 3 の流出強度と体積含水率

率が增加し、降雨強度が減少するとそれらも減少しているの がわかる。また、実験の初めの降雨強度（増加過程）と終わ りの降雨強度（減少過程）はどれも約 $25 \mathrm{~mm} / \mathrm{h}$ と同じであるが、 体積含水率の方は同じではなく終わりの方がどれも大きくな っていた。

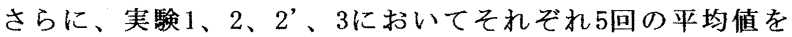
とり、両対数紙上にひとつにまとめたものが図一7である。こ の図は、縦軸は不飽和透水係数で表現してある。不飽和透水 倸数 $\mathrm{K}$ は流出強度より水頭勾配を1として算出した。また、プ

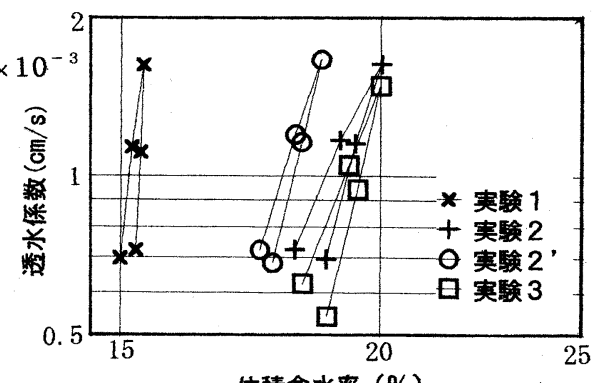

体積含水率 (\%)

図-7 平均の透水係数 $\mathrm{K}$ と体積含水率 ロットした值は5回の実験で各降雨強度毎にそれぞれ得られた $\mathrm{K} と \theta$ 值の平均值である。

図-7より、フィルム混合率が実験 $1,2\left(2^{\prime}\right), 3$ と大くなるに従って、同じ体積含水率での不飽和透水係数は 小さくなることがわかる。またこの図でも、個々の実験の図である図-3から 6 と同じように、降雨増加過程に 比べ減少過程の方が傾きが大きくなっている。 
不飽和透水俰数 $\mathrm{K}$ と体積含水率 $\theta$ との関倸について種々の関倸式が提案されているが、ここでは害験で設 定できた体積含水率の範囲が飽和に近い範囲であることから、次式で検討することとした。

$$
\mathrm{K}=\mathrm{K}_{\mathrm{s}}(\theta / \theta \mathrm{s})^{\mathrm{D}}
$$

ここに $\mathrm{K}_{\mathrm{s}}$ : 飽和透水係数、 $\theta \mathrm{s}$ : 飽和体積含水率、 $\mathrm{p}:$ 定数である。 そこで図-7の直線の傾きより増加過程、堿少過程それぞれの $\mathrm{p}$ を求めた。 $\mathrm{p}$ の決定には最小二乗法を用いた。

図-8にフィルム混合率と傾き $\mathrm{p}$ との関係を示す。図のようにフィルム があるとフィルムがない場合（フィルム混合率 $0 \%$ ）よりも傾き $\mathrm{p}$ は小さ くなる。しかし、フィルム混合率が1.26\%と $4.85 \%$ は、混合率が増加し ても傾きはあまり変化していない。また、フィルムがない場合には降雨 増加過程と减少過程での傾き $\mathrm{p}$ の差が顕著である。

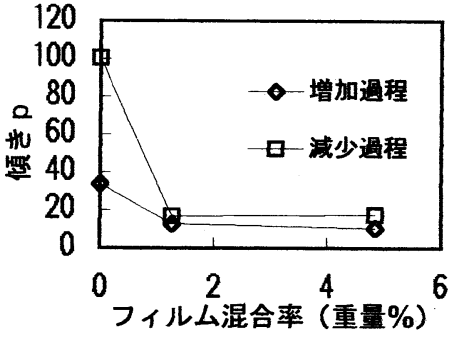

图-8フ价混合率と傾き $\mathrm{p}$

\section{2 不飽和透水係数に関するパラメータのばらつき}

上記の 3.1 では、不飽和透水保数の平均值について述べた。しかし、著者らは、廃棄物の特性としては平均 值だけでなく個々の值のばらつきそのものも重要であると考えている。このぼらつきの特性を知らねば、再 現性のある結果を得るために必要な測定回数も定められない。そこで、不飽和透水係数に関するパラメータ、

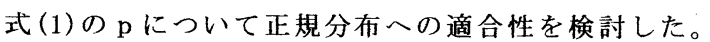

フィルムとガラスビーズの混合層を用いた実験 2 と 2 と 3 につて 5回の実験それぞれの降雨増加過程における傾き $\mathrm{p} の$ 值を、正規確率 紙にプロットしたものが図-9である。非超過確率としては、i/ $(\mathrm{n}+1)$ （ワイブル公式）を用いた。ここに、nはデータ数、iは大きさの順 番である。この図を見ると、ガラスビーズとフィルムの混合時に水 を加えなかった実験 2 に比べ、水を加えた実験2’と3の方が正規分布 に近い結果となっている。このことから、混合時に水が存在するこ とが、混ざりぐあいの偏りを小さくすると考えられる。しかし、そ の場合でも測定回数が5回では正規分布からのずれは大きい。平均的 特性を知るためにはさらに多くの回数の測定が必要だと考えられる。

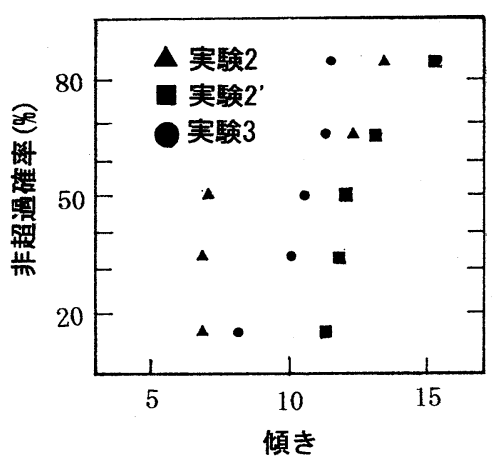

図-9 傾き $\mathrm{p}$ の出現特性

\section{4. 流出応答の特性}

\section{1 非定常応答特性}

図-10に、実験 $1 、 2 、 2 、 3 の$ 実験開始から定常になるまで の流出量の時間変化（降雨強度約 $25 \mathrm{~mm} / \mathrm{h}$ のとき）を示す。流 出量は5分間の流出量を5分間流入量の平均值で除した値で示 した。值は 5 回の実験の平均值である。図によると、定常にな るまでの時間はフィルム混合率が小さいほど短い。著者らは、 この差の原因として、水の連続性がフィルム混合率に影響さ れるためではないかと想定している。実験前に模擬廃棄物層 は一旦飽和状態にするので、実験開始直前にも模擬発棄物層 内には水が存在する。フィルムがない、あるいは少ないとき

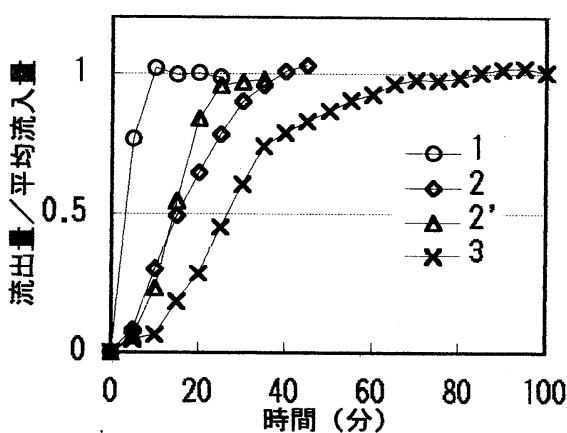

図-10 各実験平均の非定常の5分每流出量変化 にはこの水は連続している可能性が高く、連続した水の上端での変化が瞬時に下端へ伝わるため流出応答は 早くなる。このことがガラスビーズ（実験1）で定常に達するまでの時間を短くしていると考えられる。一方、 フィルムが多く含まれていると、この水の連続が途切れ、水はこの途切れをつなぎながら流れていかねばな らない。そのため定常な流れとなるまでの時間が長くなると考えられる。 
図-10では同じ材料でも水を加えて混ぜた実験2’の方が水を加えずに混ぜた実験2よりも幾分応答が早い。 この差も、混合時の水の存在が水の連続を促進するためと推定している。

以上の考えが正しければ、フィルムのような大きな面を含む廃棄物層では単に含水率を考えるだけでなく、 「水の連続」という視点での研究が重要であるといえる。

\section{2 定常応答特性}

本実験ではポンプの流入量は完全には一定とならず、5分 間の流入量が最大と最小の差で $10 \mathrm{~m} 1$ 程度の幅で僅かに変動 していた（図-2）。そこでその変動を、系が一応定常とな った後での入力の擾乱と考え、この擾乱に対する出力の応 答を検討した。ただし、データ数が30個程度なので時系列 解析は行わず、出現頻度のみを比較した。図-11、12に実験 1と3について流入量と流出量の頻度分布を示す（降雨強度 約 $25 \mathrm{~mm} / \mathrm{h}$ の時）。各図の横軸は5分毎の流入量、流出量を 5 分間流入量の平均値で除した值である。また、縦軸は実験 1では 29 回、実験 3 では 56 回の測定での出現回数である。こ れらの図を見ると流入量は平均值の回りに正規分布に近い 形で分布しているが、流出量は流入量の平均値より小さい 方に多く集まっている。この傾向はフィルムが混合してい る実験 3 方が顕著であった。また、フィルムのない実験 1 では、流入量よりも大きな変動 (平均流入量の 1.06 倍の流 出量）もみられた。この傾向が層の物性、水の連続等とど のように関係するか、またこの差がはたしてどの程度有意

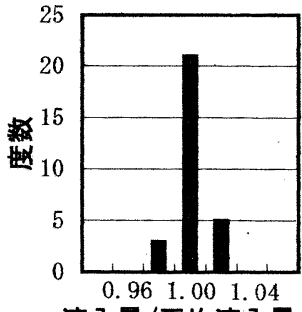

流入量/平均流入量

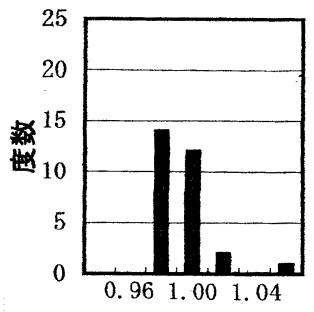

流出量/平均流入量

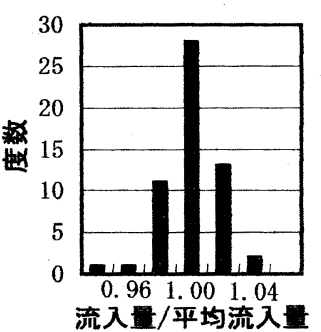

図-12 実験3増加過程の流入、流出曾変動分布 なものであるかは、現時点では不明である。

5.まとめ

ガラスビーズとフィルムを混合して作った模擬廃棄物層について、透水性および流出応答の特性を実験に より検討した。得られた主な知見は以下である。

1)ビーズにフィルムが混ざると同じ体積含水率での不飽和透水係数が小さくなった。

2)フィルムが混ざると透水性に関するパラメータ $\mathrm{p}\left(=\ln \left(\mathrm{K} / \mathrm{K}_{\mathrm{s}}\right) / \ln (\theta / \theta \mathrm{s})\right)$ は小さくなる。しかし、フィ ルム混合率 $1.26 \%$ と $4.85 \%$ では $\mathrm{p}$ 差は小さかった。

3) 降雨強度の増加過程と減少過程では、減少過程の方が $\mathrm{p} は$ 常に大きくなった。

4) 同じ材料では、ビーズとフィルムを混ぜる際に水を加えた方が $\mathrm{p}$ の分布は正規分布に近づく。

5) フィルム混合率が大きい方が流出の非定常応答はおそくなる。

6) 流出の定常応答では流出量が流入量の平均值より小さい傾向があった。また、この傾向はフィルムが混合 しているほど顕著であった。

\section{参考文献}

李南勲・楠田哲也・島岡隆行・花嶋正孝(1993)：埋立廃棄物層における水分及び保存性物質の举動に関する 研究、廃棄物学会論文誌、Vol. 4, No. 4, pp. 123-132.

田中信寿・松藤敏彦 (1993)：廃萧物埋立層における不飽和水分移動特性とその測定法に関する研究、廃棄物 学会論文誌、Vol.4, No. 3, pp. 107-115. 